\title{
Trends in Total Phosphorus Loadings and Concentrations Regarding Surface Waters of the Baltic Sea, 1968-2007
}

\author{
A.C. Bryhn* \\ Department of Earth Sciences, Uppsala University, Sweden
}

\begin{abstract}
The Baltic Sea, a large estuarine sea in northern Europe, has for many decades displayed obvious signs of anthropogenic eutrophication. This study relates long-term trends in total phosphorus (TP) loadings and TP concentrations in surface waters regarding five major sub-basins of the Baltic Sea; the Bothnian Bay, the Bothnian Sea, the Baltic Proper, the Gulf of Finland and the Gulf of Riga. The longest time series ever published on these variables was developed and used for this purpose. TP loadings to these waters have decreased greatly and significantly since the 1980 s. However, TP concentrations have only decreased slightly in one of the sub-basins while concentrations have increased in the other four basins. Four possible hypotheses about the weak connection between TP loadings and concentrations are 1) increasing TP concentration is a delayed effect from many decades of intensive TP loading, 2) fewer saline inflows of high intensity have decreased sedimentation rates and increased TP concentrations, 3) fewer oxygen-rich saline inflows of high intensity have increased TP diffusion from deep sediments to the whole water column and 4) less ice in the winter has increased the erosion and resuspension of shallow sediments and increased TP concentrations.
\end{abstract}

Keywords: Eutrophication, total phosphorus, the Baltic Sea, loading, concentration.

\section{INTRODUCTION}

Eutrophication in the Baltic Sea (northern Europe) has for many decades been a widespread concern in the surrounding countries. Low Secchi depth and intensive summer blooms of cyanobacteria have been two eutrophication signs which have been associated with elevated levels of anthropogenic nutrient loads to this large estuary. Empirical data constitute the primary foundation for all types of environmental analysis connected to causes and effects [1] and much of the pastime Baltic Sea research has therefore been directed towards detecting long-term trends in improving indicator variables. Previous studies on long-term trends highlighted eutrophication effects and their temporal variation in the Baltic Sea and have focused on, e. g., total phosphorus (TP) loadings [2], riverine TP and total nitrogen (TN) loadings [3], the Secchi depth [4], concentrations of chlorophyll-a $[1,5]$, biomasses of phytoplankton groups [5], and TP concentrations [1].

Nutrients and algal blooms are, however, to some extent natural to the Baltic Sea [6]. One hundred years ago, the nutrient loss from human activity was substantial in the Baltic Sea catchment. Natural fertilisers were used in agriculture, and horses were intensively used for transportation in urban and rural areas. Sewage systems were constructed to prevent outbreaks of cholera and other diseases in the cities but sewage treatment was absent or very ineffective in many areas until after the Second World War [7].While human activity

*Address correspondence to this author at the Department of Earth Sciences, Uppsala University, Sweden

E-mail: andreas.bryhn@geo.uu.se contributed to large nutrient inputs already one century ago, the effects from this activity did not become apparent in the open sea until the late 1960s when cyanobacterial blooms became a recurring nuisance [8].

Phosphorus is a key nutrient in the context of Baltic Sea eutrophication $[1,7,9,10]$. Since costly TP reductions have been undertaken extensively in most of the surrounding countries, it should be of great interest to managers and the scientific community to be able to compare how the TP loading has varied in relation to TP concentrations. The present study therefore partly aims at expanding present knowledge on TP concentrations in surface waters of five major subbasins of the Baltic Sea; the Bothnian Bay (BB), the Bothnian Sea (BS), the Baltic Proper (BP), the Gulf of Finland (GF) and the Gulf of Riga (GR). The idea is to determine long-term time trends from the 1960s or 1970s to recent years in these basins. Håkanson and Lindgren [1] presented TP trends from 1990 in the Baltic Proper only, which means that the coming analysis will be much more comprehensive. The analysis is restricted to surface waters since this is where algal blooms and other types of primary production occur. Finally, the TP loading data from two different literature sources will be combined and made mutually compatible and adjusted to describe loadings to the five mentioned subbasins. The resulting time-series will be compared with TP concentration trends.

\section{MATERIALS AND METHODS}

Surface waters were defined as being located above the theoretical wave base [11]. This is the depth below which wind and wave action normally do not reach and the depth at which the thermocline may typically be found. The theoreti- 
cal wave base is also an important divider for sediments; above this depth, sediments are generally affected by erosion and transportation processes, while sediment accumulation dominates bottom areas below the theoretical wave base. The theoretical wave base is located at $41.1 \mathrm{~m}$ depth in the $\mathrm{BB}$, at $42.5 \mathrm{~m}$ in the $\mathrm{BS}$, at $43.8 \mathrm{~m}$ in the $\mathrm{BP}$, at $43.8 \mathrm{~m}$ in the $\mathrm{GF}$, and at $39.2 \mathrm{~m}$ in the GR [11]. It should be noted that the actual wave base could be located at quite different depths than these during extreme meteorological events such as major storms or long calm periods.

TP loading data were taken from [3] and [12] and concerned monitored and unmonitored rivers, coastal areas and point sources. From 2003, loads from direct diffuse sources were also included [12]. Data on freshwater inflow emanate from [13] and have mostly been collected by means of direct measurements, although part of the data have been estimated with runoff models. Helcom data on TP concentrations were downloaded from [14] and separated into those five major basins of the Baltic Sea which were mentioned in the introduction. The dense spatial distribution of Helcom's sampling stations in the Baltic Sea is described in [14]. Trends were determined by means of linear regression using the software R.

\section{RESULTS}

Table 1 presents the freshwater inflow $\left(Q_{\text {Trib }}\right)$ and TP loadings to the five basins of the Baltic Sea mentioned in the introduction. Data on TP inflow from 1970-1993 emanate from [3] and were specified for each year with respect to the loadings from rivers. Point sources along the coastline were reported to contribute with $12.5 \mathrm{kt} / \mathrm{yr}$ during this period to an area, which included Kattegat and the Belt Sea [3], two areas which were beyond the focus of the present study. These two areas received about $28 \%$ of the TP loading to the Baltic Sea plus Kattegat and the Belt Sea in the early 1980s [15] and $16 \%$ of the loading in 1990 [16], so in Table $\mathbf{1}$, I have estimated that TP from coastal point sources to the Baltic Sea was $12.5 \cdot(1-[0.28+0.16] / 2)=9.8 \mathrm{kt}$ per year. The mean annual freshwater inflow in [3] (my estimate from graphs in this source was $449 \mathrm{~km}^{3}$ ) corresponded very well with 1970 1993 data in [13] (the mean annual inflow was $452 \mathrm{~km}^{3}$ ). TP loading data from 1994-2005 in Table 1 have been taken from [12], and this source provided the total loading to the Baltic Sea plus the Belt Sea and Kattegat. In 1995, the latter two areas received $10.4 \%$ of the TP loading to the area covered by [12] according to [17] while this figure was $8.4 \%$ for the year 2000 [18]. Thus, table 1 contains TP loadings from [12] minus $(10.4 \%+8.4 \%) / 2=9.4 \%$.

One can note from Table 1 that the TP loading was very high in the $1980 \mathrm{~s}$, at a mean value of $48 \mathrm{kt} / \mathrm{yr}$, lower in the $1970 \mathrm{~s}(40 \mathrm{kt} / \mathrm{yr})$, lower yet in the 1990s (36 kt/yr) and that the lowest loadings were recorded during the first six years of the present decade (mean value: $28 \mathrm{kt} / \mathrm{yr}$ ). The freshwater inflow has also varied considerably, and was about 420 $\mathrm{km}^{3} / \mathrm{yr}$ in the $1970 \mathrm{~s}, 480 \mathrm{~km}^{3} / \mathrm{yr}$ in the $1980 \mathrm{~s}, 460 \mathrm{~km}^{3} /$ year in the $1990 \mathrm{~s}$ and $430 \mathrm{~km}^{3} / \mathrm{yr}$ during 2000-2007. Data from Table 1 were subsequently used for calculating the mean, flow-weighted TP concentration in the inflow from the catchment to the Baltic Sea 1970-2005 and the result is displayed in Fig. (1). It is also clear from this graph that the most accentuated TP pollution, as expressed in TP concen-
Table 1. Total Phosphorus (TP) Loading and Freshwater Inflow $\left(Q_{\text {Trib }}\right)$ to the Baltic Sea. TP Loading Data for 1970-1993 from [3]; TP Loading Data for 1994-2005 from [12]; $Q_{\text {Trib }}$ Data from [13]

\begin{tabular}{|c|c|c|}
\hline Year & TP Loading (kt) & $\mathbf{Q}_{\text {Trib }}\left(\mathrm{km}^{3}\right)$ \\
\hline 1970 & 43 & 421 \\
\hline 1971 & 38 & 398 \\
\hline 1972 & 36 & 379 \\
\hline 1973 & 34 & 365 \\
\hline 1974 & 45 & 467 \\
\hline 1975 & 41 & 453 \\
\hline 1976 & 34 & 340 \\
\hline 1977 & 45 & 461 \\
\hline 1978 & 43 & 441 \\
\hline 1979 & 45 & 455 \\
\hline 1980 & 50 & 448 \\
\hline 1981 & 53 & 545 \\
\hline 1982 & 45 & 477 \\
\hline 1983 & 42 & 463 \\
\hline 1984 & 42 & 464 \\
\hline 1985 & 48 & 483 \\
\hline 1986 & 50 & 463 \\
\hline 1987 & 50 & 517 \\
\hline 1988 & 54 & 498 \\
\hline 1989 & 49 & 478 \\
\hline 1990 & 46 & 469 \\
\hline 1991 & 43 & 443 \\
\hline 1992 & 40 & 464 \\
\hline 1993 & 40 & 456 \\
\hline 1994 & 33 & 447 \\
\hline 1995 & 36 & 482 \\
\hline 1996 & 26 & 367 \\
\hline 1997 & 31 & 421 \\
\hline 1998 & 36 & 553 \\
\hline 1999 & 33 & 470 \\
\hline 2000 & 33 & 515 \\
\hline 2001 & 30 & 490 \\
\hline 2002 & 30 & 428 \\
\hline 2003 & 21 & 339 \\
\hline 2004 & 26 & 431 \\
\hline 2005 & 26 & 438 \\
\hline 2006 & n. a. & 358 \\
\hline 2007 & n. a. & 432 \\
\hline
\end{tabular}

n. a.: not available. 




Fig. (1). Mean flow-weighted total phosphorus concentrations in the inflow $\left(\mathrm{TP}_{\text {in }}\right)$ from the catchment to the Baltic Sea, 1970-2005. Data from Table 1.

tration in the inflow, to the Baltic Sea occurred in the 1980s. A trend analysis showed that the mean TP concentration in the inflow has decreased significantly during 1970-2005 $\left(\mathrm{r}^{2}\right.$ $=0.64, \mathrm{p}<0.001)$. The $1970-2005$ trend was also significant for the TP load $\left(r^{2}=0.32, p<0.001\right)$ while the 1970-2007 trend in freshwater inflow was insignificant $(\mathrm{p}=0.32)$.

Fig. (2) shows TP concentrations in surface waters of the BB. Before 1975 and during 1976 and 1978, data were scattered so no reliable annual mean or median values could be calculated and the analysis therefore stretched from 1975 to 2007 regarding this sub-basin. During this period, there was a slight but significant decrease in TP concentration. Concentrations have generally fluctuated around $6 \mu \mathrm{g} / 1$, and high concentrations were often measured in the 1980s. The BB thereby had the lowest TP concentrations and was the only one with decreasing concentrations among the sub-basins. TP concentrations in the BS are displayed in Fig. (3). Data during the earliest part of the period were scattered and not available for all seasons. There was a significant $(p<0.001)$ increase in concentration 1974-2007 and some of the highest concentrations have been measured during recent years. Medians increased from about $9.0 \mu \mathrm{g} / \mathrm{l}$ during 1974-1979, via

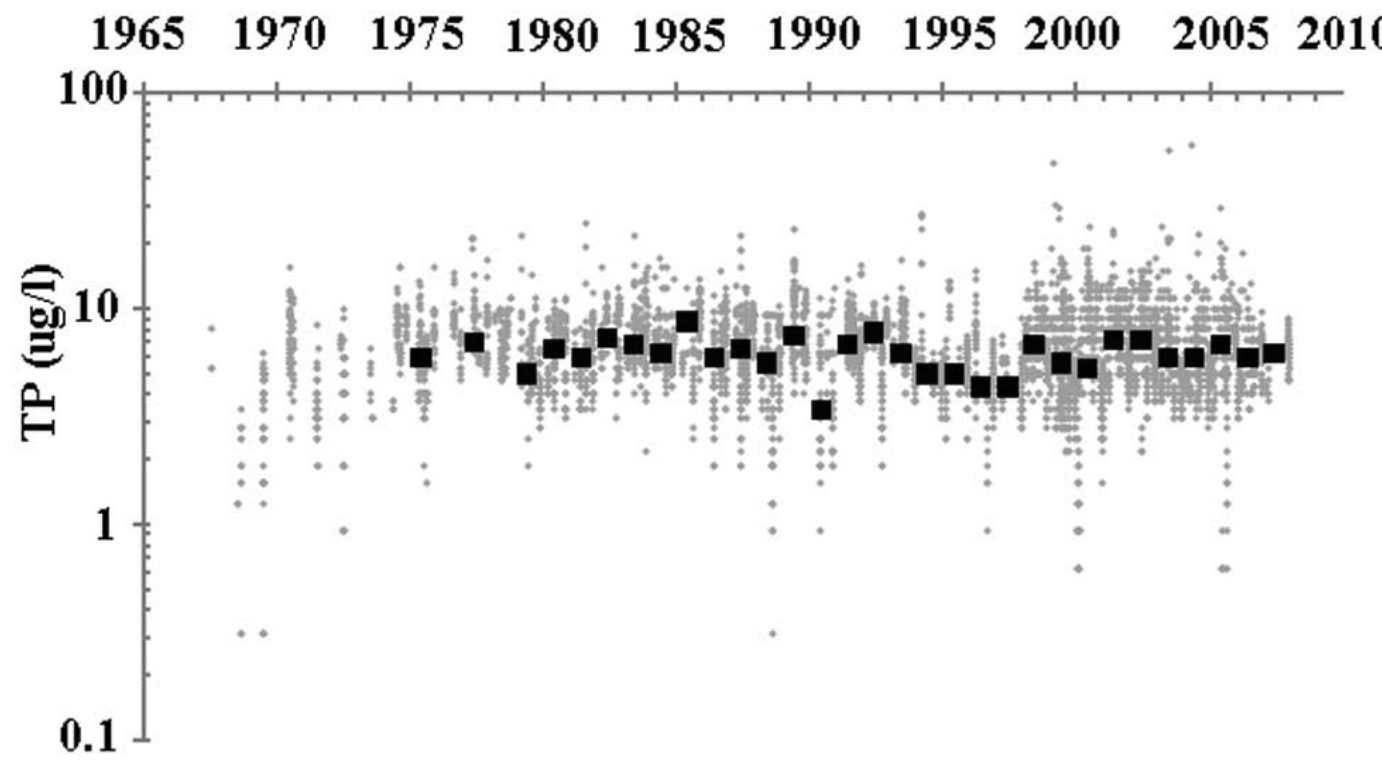

Fig. (2). Total phosphorus (TP) concentrations $(\mu \mathrm{g} / \mathrm{l})$ in the surface-water layer of the Bothnian Bay. Black squares denote yearly medians. Trend slope 1975-2007 was $-0.014 \mu \mathrm{g} /(1 \cdot$ year $), \mathrm{r}^{2}=0.002, \mathrm{p}=0.005$, number of data: 5053 . 


\section{$\begin{array}{llllllllll}1965 & 1970 & 1975 & 1980 & 1985 & 1990 & 1995 & 2000 & 2005 & 2010\end{array}$}

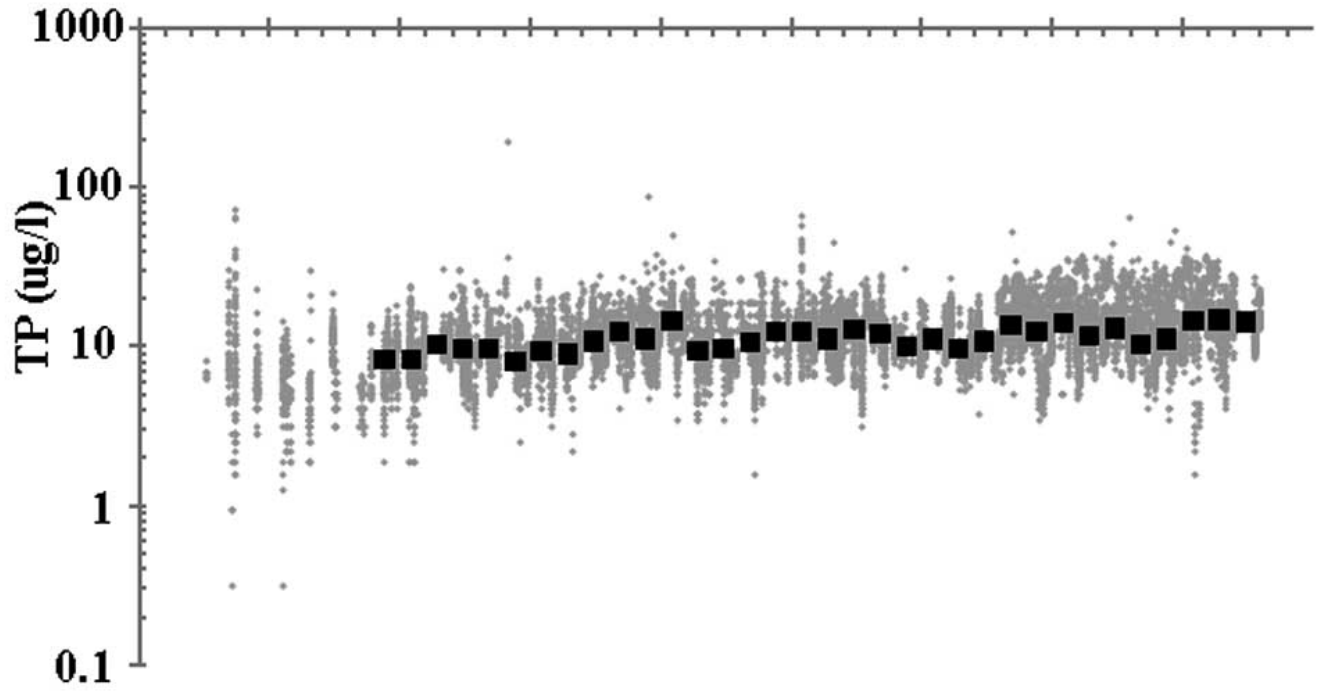

Fig. (3). Total phosphorus (TP) concentrations $(\mu \mathrm{g} / \mathrm{l})$ in the surface-water layer of the Bothnian Sea. Black squares denote yearly medians. Trend slope 1974-2007 was $+0.15 \mu \mathrm{g} /(1 \cdot$ year $), \mathrm{r}^{2}=0.069, \mathrm{p}<0.001$, number of data: 10454 .

$11 \mu \mathrm{g} / 1$ in the $1980 \mathrm{~s}$ and $12 \mu \mathrm{g} / 1$ in the $1990 \mathrm{~s}$, to about 13 $\mu \mathrm{g} / \mathrm{l}$ during 2000-2007.

Fig. (4) describes TP in surface waters of the BP 19682007. The long-term trend has clearly been increasing from 1968 to $2007\left(\mathrm{r}^{2}=0.03, \mathrm{p}<0.001, \mathrm{n}=48,978\right)$. The highest TP concentrations have generally been measured during recent years (2004-2007), and the period 1983-1992. Particularly high concentrations were recorded in 2005. Medians have increased from about $15 \mu \mathrm{g} / 11968-1979$ to $21 \mu \mathrm{g} / 1$ in the $1980 \mathrm{~s}$, decreased slightly to $19 \mu \mathrm{g} / \mathrm{l}$ in the $1990 \mathrm{~s}$ and increased again to about $22 \mu \mathrm{g} / \mathrm{l}$ during 2000-2007. The Baltic Proper had the longest time-series on TP concentrations in surface waters among the sub-basins.

In the GF, TP concentrations have also increased significantly $(\mathrm{p}<0.001)$ during recent decades (Fig. 5). Data covering all seasons were available from 1975, 1977-1982 and 1984-2007. In the late 1970 s, medians increased steadily, from $19 \mu \mathrm{g} / 11975$ to $30 \mu \mathrm{g} / 1$ 1979. Medians fluctuated around $27 \mu \mathrm{g} / 1$ in the $1980 \mathrm{~s}$ and $1990 \mathrm{~s}$, and around $31 \mu \mathrm{g} / 1$ during 2000-2007. The GF has had the most accentuated

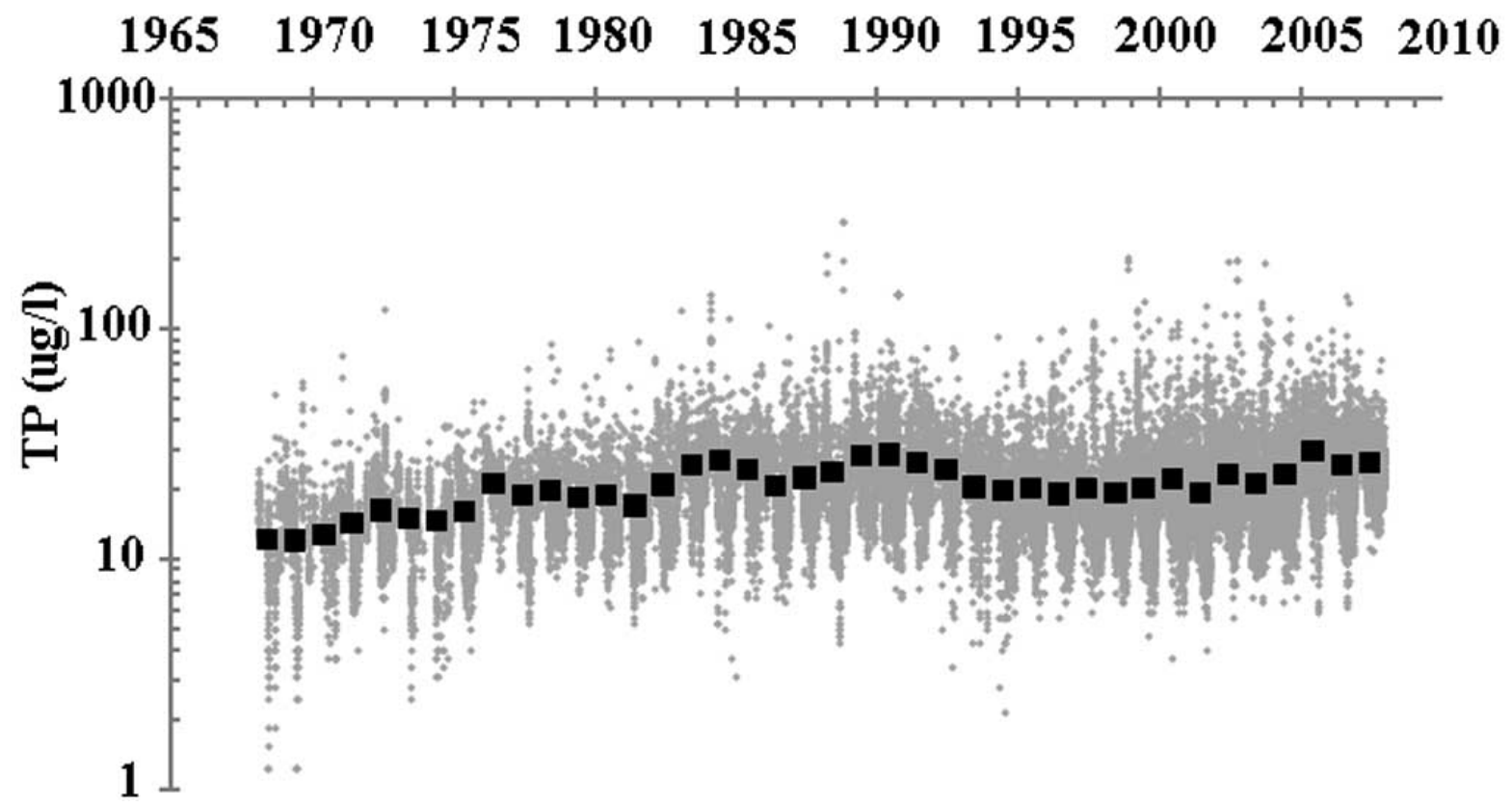

Fig. (4). Total phosphorus (TP) concentrations $(\mu \mathrm{g} / 1)$ in 1968-2007 in the surface-water layer of the Baltic Proper. Black squares denote yearly medians. Trend slope was $+0.19 \mu \mathrm{g} /(1 \cdot$ year $), \mathrm{r}^{2}=0.03, \mathrm{p}<0.001$, number of data: 48978 . 
long-term concentration increase which could be documented among the sub-basins. Finally, there was also an increasing concentration trend in the GR (Fig. 6), although there were only data available for the period 1986-2007. In the late $1980 \mathrm{~s}$, concentrations varied around $27 \mu \mathrm{g} / 1$, around $29 \mu \mathrm{g} / 1$ in the $1990 \mathrm{~s}$ and near $31 \mu \mathrm{g} / 1$ during 2000-2007. The GR and the GF thus had higher TP concentrations than the other sub-basins.

\section{DISCUSSION}

The findings in the Results section make it clear that changes in TP loadings were poorly reflected in TP concentrations in surface waters of the Baltic Sea. Conley et al. [2] also noted a poor correlation between phosphorus loadings from land and phosphate concentrations in the water column of the BP, the GF and the GR, 1970-1998. The present work has confirmed that still towards the end of the present decade, there had been a very scant response in surface waters from long-term loading reductions to the five major subbasins of the Baltic Sea. There is only one sub-basin which has had decreasing surface water TP concentrations during recent decades, the $\mathrm{BB}$ (Fig. 2), and even in this basin, decreases have been very modest. There may be several explanations to the poor outcome from loading reductions, and some previously presented and other possible explanations are:

1. Increasing TP concentrations in surface waters may be a delayed effect from many years of increasing TP loadings. Previously added anthropogenic phosphorus may be temporarily stored in sediments and deeper water layers. Savchuk and Wulff [10] calculated that only about 3.5\% of the phosphorus utilised by primary producers in the $\mathrm{BP}$ comes from simultaneous land inputs. The remaining part is already stored in the system. Due to the long phosphorus retention time in the system, expectations re- garding decreasing phosphorus concentrations after phosphorus abatement in the catchment should need to be modest [10].

2. The frequency of major inflows of saline, oxygen-rich water from the Kattegat to the Baltic Sea has been exceptionally low during recent decades [19]. High salinity enhances the flocculation and aggregation of particles and increases the sedimentation of particulate matter [20], including particulate nutrients. The limited salt input from the Kattegat may thereby have halted phosphorus sedimentation and sustained high TP concentrations.

3. Low frequency of intensive saltwater intrusions may also have lowered oxygen concentrations in deep waters and increased phosphorus diffusion from deep sediments [10, 21]. Conley et al. [2] successfully correlated the extent of hypoxic bottom areas with dissolved inorganic phosphorus concentrations in the water column during winters. An intensified phosphorus release from deep sediments may strongly affect TP concentrations in surface waters [21]. Deep, hypoxic sediments are most prevalent in the BP which may even be a net source of TP while the other sub-basins probably serve as sinks [21].

4. The extent of sea ice has been notably small during recent decades in the Baltic Sea [22]. Ice may effectively prevent sediment resuspension in marine environments [23]. This is illustrated in Fig. (7) and exemplified for the Bothnian Sea. Ice in the Baltic Sea usually first covers waters near the coast, and these waters to a relatively great extent affect bottom areas where erosion and transport processes dominate. Furthermore, as the ice spreads, the open water areas decrease and thereby the effective fetch over which the wind blows decreases and also the theoretical wave base and the area of sediments which can be reached by wave action. When the ice has de-



Fig. (5). Total phosphorus (TP) concentrations $(\mu \mathrm{g} / \mathrm{l})$ in the surface-water layer of the Gulf of Finland. Black squares denote yearly medians. Trend slope 1975-2007 was $+0.29 \mu \mathrm{g} /(1 \cdot$ year $), \mathrm{r}^{2}=0.012, \mathrm{p}<0.001$, number of data: 8657 . 


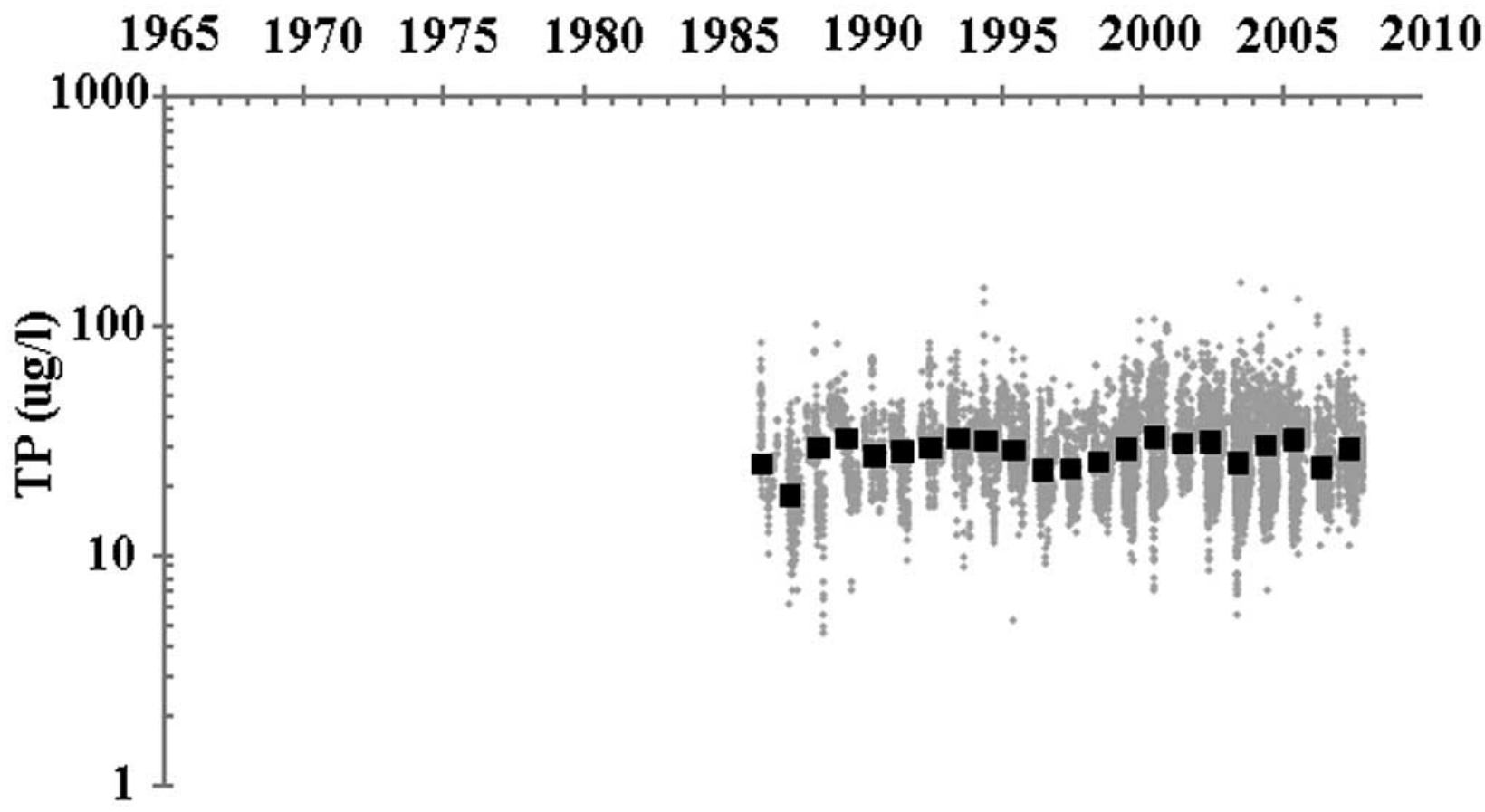

Fig. (6). Total phosphorus (TP) concentrations $(\mu \mathrm{g} / \mathrm{l})$ in the surface-water layer of the Gulf of Riga. Black squares denote yearly median. Number of data: 7441 . Trend slope 1986-2007 was $+0.097 \mu \mathrm{g} /(1 \cdot y e a r), \mathrm{r}^{2}=0.002, \mathrm{p}<0.001$.

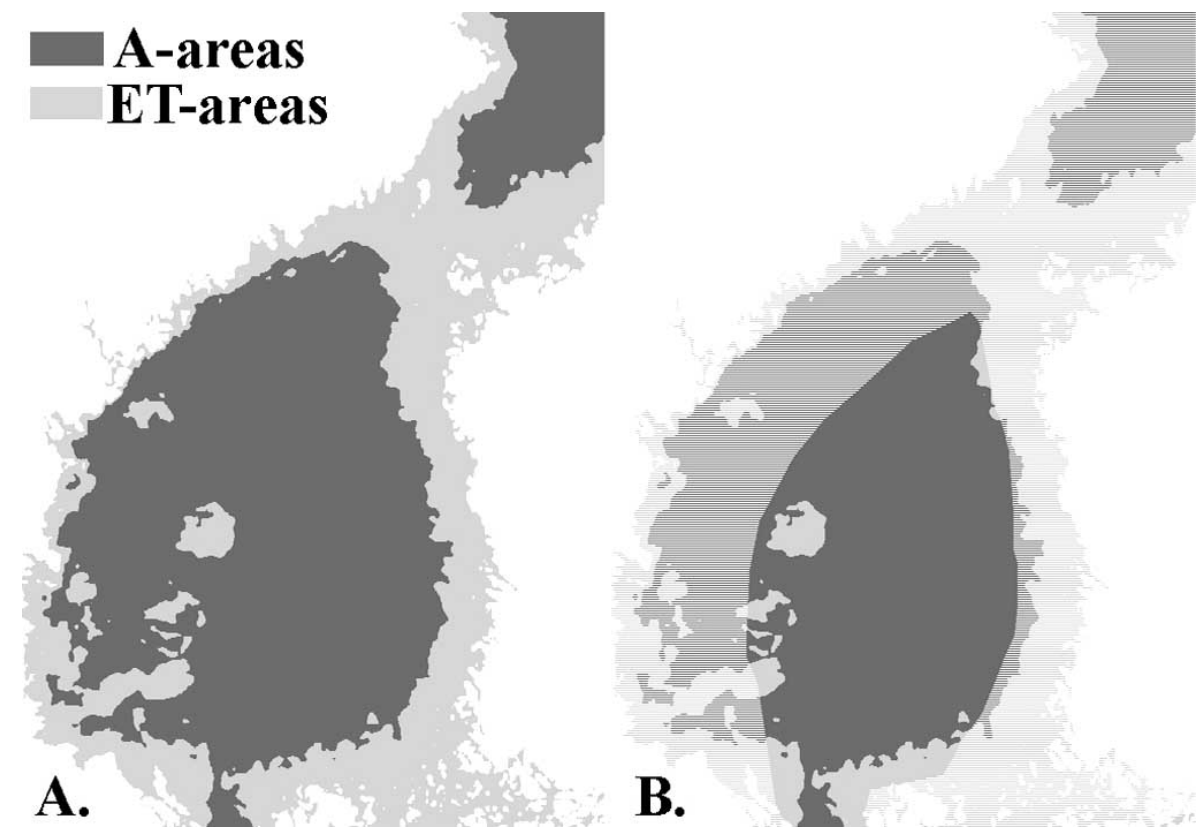

Fig. (7). Illustration of ice cover and bottom dynamic conditions (ET, A) in the Bothnian Sea. A. Ice free conditions (summer). B. Maximum ice extent (shaded areas) and open waters during a very mild winter. A-areas = areas of sediment accumulation, ET-areas $=$ areas of sediment erosion and transportation.

creased in extent, this may have exposed large areas of erosion and transport sediments to more wave action than during normal conditions. A shrinking ice cover may have increased sediment erosion and resuspension and thus added substantial amounts of phosphorus to the water column.
5. There are still some major anthropogenic TP sources left in the catchment which may relatively inexpensively be diminished; e. g., emissions in the form of urban sewage in former East Bloc countries [9]. The TP concentration in the Baltic Sea may have crossed a threshold level [24] and additional efforts may be required before a general concentration decrease can be expected. 
6. Intensive nitrogen loading from land may have increased TP concentrations in a "vicious circle" where nitrogenlimited algae sink to the bottom and the decomposition of these algae consumes oxygen. According to this theory, low oxygen concentrations near deep sediments also greatly increase the diffusion of sediment-bound phosphorus into the water column [25].

It should be stressed that these possible reasons, or hypotheses, regarding the general long-term increase in TP concentrations of Baltic Sea surface waters must be quantitatively assessed, and there may be few ways to do this other than by means of a mass-balance model which can quantitatively explain the difference in nitrogen and/or phosphorus cycles between the five basins. At present, there are no such models available for nitrogen but only for phosphorus [9, 11]. Furthermore, the very fact that it has been possible to construct a general dynamic phosphorus model which does not take nitrogen loadings into account but which uses a unitary set of equations and model constants and gives good predictions of recent TP concentrations in all of the five subbasins investigated in this work contradicts hypothesis number six [11]. Finally, riverine nitrogen loads peaked in the 1980s [3] and have been stable since the mid-1990s [12] while a stable atmospheric nitrogen deposition has also been noted since the mid-1990s [26] which makes it difficult to present comprehensive empirical support for this hypothesis.

A non-linear trend shift in TP concentrations has allegedly occurred in the Baltic Proper in the 1990s (sometimes referred to as "the flip"; see [1] and references therein). However, Håkanson and Lindgren [1] found no significant TP concentration trend shifts in any water layer of the Baltic Proper during this period, which could weaken the case for hypothesis number five. The remaining four hypotheses may well be further tested quantitatively, although this lies beyond the scope of the present work.

\section{CONCLUSIONS}

The present study has investigated long-term trends in TP loading and concentrations regarding surface waters of the Baltic Sea. This has resulted in the longest published time series and time trends thus far regarding TP concentrations in the Bothnian Bay (1975-2007), the Bothnian Sea (19742007), the Baltic Proper (1968-2007), the Gulf of Finland (1975-2007) and the Gulf of Riga (1986-2007). Furthermore, an exceptionally long time-series on TP loadings to these combined sub-basins was made compatible for the period 1970-2005. These results could be very useful for future phosphorus mass-balance modelling of the Baltic Sea and its major sub-basins.

Phosphorus concentrations have largely remained high despite many years of phosphorus abatement efforts. The TP loading peaked in the 1980 s while concentrations have increased until 2007 in all sub-basins except for the Bothnian Bay where there has been a very slight concentration drop. Loadings and surface water concentrations of TP have thereby shown quite different patterns in the Baltic Sea. Four presently testable and possible hypotheses why the patterns differ are 1) increasing concentrations is a delayed effect from many decades of intensive loading, 2) fewer saline inflows of high intensity have decreased sedimentation rates and increased concentrations, 3) fewer saline and oxygen- rich inflows have increased phosphorus diffusion from deep sediments and 4) less ice in the winter has increased the erosion and resuspension of shallow sediments and increased concentrations. Whether one or several of these hypotheses could quantitatively explain the difference between loading and concentration patterns described in the present work remains to be determined.

\section{ACKNOWLEDGEMENTS}

Comments from two anonymous reviewers have greatly improved the final version of this paper.

\section{REFERENCES}

[1] Håkanson L, Lindgren D. On regime shifts and budgets for nutrients in the open Baltic Proper: evaluations based on extensive data between 1974 and 2005. J Coast Res 2008; 24: 246-60.

[2] Conley DJ, Humborg C, Rahm L, Savchuk OP, Wulff, F. Hypoxia in the Baltic Sea and basin-scale changes in phosphorus biogeochemistry. Environ Sci Technol 2002; 36: 5315-20.

[3] Stålnacke P, Grimvall A, Sundblad K, Tonderski A. Estimation of riverine loads of nitrogen and phosphorus to the Baltic Sea, 19701993. Environ Monit Assess 1999; 58: 173-200.

[4] Sandén P, Håkansson B. Long-term trends in Secchi depth in the Baltic Sea. Limnol Oceanogr 1996; 41: 346-51.

[5] Wasmund N, Uhlig S. Phytoplankton trends in the Baltic Sea. ICES J Mar Sci 2003; 60: 177-86.

[6] Bianchi TS, Engelhaupt E, Westman P, Andren T, Rolff C, Elmgren R. Cyanobacterial blooms in the Baltic Sea: natural or humaninduced? Limnol Oceanogr 2000; 45: 716-26.

[7] Savchuk OP, Wulff F, Hille S, Humborg C, Pollehne F. The Baltic Sea a century ago - a reconstruction from model simulations, verified by observations. J Mar Syst 2008; 74: 485-94.

[8] Finni T, Kononen K, Olsonen R, Wallström K. The history of cyanobacterial blooms in the Baltic Sea. Ambio 2001; 30: 172-8.

[9] Bryhn AC. Sustainable phosphorus loadings from effective and cost-effective phosphorus management around the Baltic Sea. PLoS ONE 2009; 4: e5417.

[10] Savchuk O, Wulff F. Modelling regional and large-scale response of Baltic Sea ecosystems to nutrient load reductions. Hydrobiologia 1999; 393: 35-43.

[11] Håkanson L, Bryhn AC. Eutrophication in the Baltic Sea. Berlin/Heidelberg: Springer 2008; p. 261.

[12] Helcom [homepage on the Internet]. Waterborne inputs of nitrogen and phosphorus. Indicator Fact Sheets 2007; [cited: 27 Feb 2009]. Available from: http://www.helcom.fi/environment2/ifs/ifs2007/en_GB/nutrient_load/

[13] Helcom [homepage on the Internet]. Total and regional runoff to the Baltic Sea. Indicator Fact Sheets 2008; 2008 [cited: 27 Feb 2009]. Available from: http://www.helcom.fi/environment2/ifs/ifs2008/en GB/Runoff/

[14] ICES [homepage on the Internet].HELCOM data. ICES, Copenhagen; 2009 [cited: 2009 Feb 27]. Available from: http://www.ices.dk/ocean/asp/helcom/helcom.asp?Mode $=1$

[15] Helcom. First Baltic Sea pollution load compilation. Baltic Sea environment proceedings 20. Helcom, Helsinki 1987; p. 57.

[16] Helcom. Second Baltic Sea pollution load compilation. Baltic Sea environment proceedings 45. Helcom, Helsinki. 1993; p. 162.

[17] Helcom. Third Baltic Sea pollution load compilation. Baltic Sea environment proceedings 70. Helcom, Helsinki. 1998; p. 134.

[18] Helcom. Fourth Baltic Sea pollution load compilation. Baltic Sea environment proceedings 93. Helcom, Helsinki 2004; p. 189.

[19] Meier HMM. Modeling the pathways and ages of inflowing saltand freshwater in the Baltic Sea. Estuar Coast Shelf Sci 2007; 74 610-27.

[20] Håkanson L. The relationship between salinity, suspended particulate matter and water clarity in aquatic systems. Ecol Res 2006; 21: 75-90.

[21] Savchuk OP. Resolving the Baltic Sea into seven subbasins: N and P budgets for 1991-1999. J Mar Syst 2005; 26: 1-15.

[22] Eriksson C, Omstedt A, Overland JE, Percival DB, Mofjeld HO. Characterizing the European sub-Arctic winter climate since 1500 using ice, temperature, and atmospheric circulation time series. J Clim 2007; 20: 5316-34. 
[23] Ramseier RO, Bauerfeind E, Garrity C, Walsh ID. Seasonal variability of sediment trap collections in the Northeast Water Polynya. Part 1: Sea-ice parameters and particle flux. J Mar Syst 1997; 10: 359-69.

[24] Scheffer M, Carpenter S, Foley JA, Folke C, Walker B. Catastrophic shifts in ecosystems. Nature 2001; 413: 591-6.
[25] Vahtera E, Conley DJ, Gustafsson BG, et al. Internal ecosystem feedbacks enhance nitrogen-fixing cyanobacteria blooms and complicate management in the Baltic Sea. Ambio 2007; 36: 186-94.

[26] Helcom [homepage on the Internet]. Atmospheric nitrogen depositions to the Baltic Sea during 1995-2006. Helcom, Helsinki; 2008 [cited: 09 June 2009]. Available from: http://www.helcom.fi/environment2/ifs/ifs2008/en GB/n deposition/

Received: June 11, 2009

Revised: September 14, 2009

Accepted: October 14, 2009

(C) A.C. Bryhn; Licensee Bentham Open.

This is an open access article licensed under the terms of the Creative Commons Attribution Non-Commercial License (http://creativecommons.org/licenses/ by-nc/3.0/) which permits unrestricted, non-commercial use, distribution and reproduction in any medium, provided the work is properly cited. 